\section{Lacteal Secretion in the Male.}

Chicago, Nov. 30, 1908.

To the Editor:-The remarks of Dr. Gellhorn, in his excellent article in THE Journal, November 28, on "Abnormal Mammary Secretion," etc., in re the rarity of lacteal secretion in the male, recalls to my mind a case that may be of interest: A youth, 17 years of age, serving sentence for highway robbery, came under my care during my term of service at the Penitentiary Hospital, Blackwell's Island, N. Y. He was sultering from some minor pulmonary trouble-bronchitis, as I remember it. Ife objected to being stripped for examination. When this was done, it was found that his sensitiveness was due to his humiliation over the possession of two well-developed mammæ, of about the size of the average virginal breast at puberty. From these breasts $I$ freely expressed lacteal secretion in moderate quantity and of a quality which, as shown by chemical and microscopic examination, was fully equal to the average standard of female lacteal secretion. According to the history, the condition had existed for about a year. The cause was unknown and the subject otherwise normal, the sexual apparatus being well developed.

As is true of most such institutional cases, the subject was lost sight of after he had served his term of punishment. Interne like, I regarded the case as a curio and did not recognize its scientific value, hence did not at that time report it. I have a hazy notion that $I$ afterward did so, but if so, the journal in which it was reported is beyond my recollection.

G. FRANK Lydston:

\section{Sea-Water in Tuberculosis and Other Diseases. Valdez, Alaska, Nov. 20, 1908.}

To the Editor:-For the past two years I have been experimenting with sea-water as a remedial agent in tuberculosis, anemia, chlorosis and dyspepsia, and the result has been so gratifying that I feel constrained to publish the facts. I have had over twelve cases of pulmonary tuberculosis; four of the patients were bed-ridden. One patient gained 35 pounds in three months, another 16 pounds in one month, and after the first quart of sea-water ceased to have night sweats. Another patient gained 12 pounds in six weeks. All these patients have retained their weight, are apparently well, and have normal temperature. I have had the same experience in cases of anemia, chlorosis and some forms of dyspepsia, and I urge that a thorough test be made of sea-water in these diseases. My method is to have the patients drink from 1 to 3 pints of sea-water each day, and $I$ have found that after taking it a day or two, the patients not only do not object to it, but seem to like it. Dr. Charles, in the British Medical Journal, reports some very interesting experiments with seawater. He advocates diluting it with natural potable water, in the proportion of two parts to five; but $I$ have found that there is very little objection to drinking it in its natural state. It is impossible, in the cities remote from the sea, to obtain the fresh sea-water, and I have had some carbonated, which renders it more palatable and equally efficacious.

\section{E. C. DALTON.}

\section{Queries and Minor Notes}

Anonymods Communications will not be noticed. Queries for this column must be accompanied by the writer's name and address, but the request of the writer not to publish name or address dress, but the request of th
will be faithfully observed.

\section{JOURNALS ON OPHTHALMOLOGY, OTOLOGY AND} LARYNGOLOGY.

To the Editor:-Please give the names of the best and leading joul'nals on ophthalmology, otology and laryngology.

$$
\text { J. M. GARBER. }
$$

ANSwER.-The following are representative journals:

Annals of Otology, Rhinology and Laryngology, Mermod-Jaccard

Bldg., St. Louis, \$4 a rear.

Annals of Ophthalmology, Mermod-Jaccard Bldg., St. Louis, $\$ 4$ a

year; with Annals of Otology, Rhinology and Laryngology, $\$ 7$ a rear.

Laryngoscope, 3858 Westminster Pl., St. Louis, $\$ 3$ a year.

Ophthalmic Record, 72 Madison St., Chicago, $\$ 4.50$ a year.
Journal of Ophthalmology and Oto-Laryngology, 100 State St., Chicago, \$2 a year.

Ophthalmology, 105 Grand Ave., Milwaukee, \$5 a year.

Journal of Laryngology, Rhinology and Otology, 21 st. Thomas St., London, S.E., England, \$5 a year, including postage.

Archives of Ophthalmology. (Am. ed.), New Rochelle, N. Y., b1monthly. $\$ 4.50$ a year.

Archives of otology (Am. ed.), New Rochelle, N. Y., bi-monthly, $\$ 4.50$ a year.

The two last named are the American editions of the German journals of the same name.

\section{HYDRARGYRUM SUCCINIDUM.}

EAgle Grove, Iowa, Dec. 2, 1908.

To the Elitor:-In the article on "Treatment of Tuberculosis by Mercury" in THE Joursal, Nov. 28, 1908, I come on this chemical product in closing the article. I do not ask, what is this, because I presume it may be possible to be amber mercury in such a way as to make it either a succinimid or a succinamid, an ammonia delivative of succinic acid. But is this salt official? This preparation is not mentioned in the U. S. Pharmacopeia, the Dispensatory the National Formulary or New and Nonofficial Remedies. Why then shouid this rare chemical salt be the one selected in the very long list of mercurials avallable? That tuberculosis and syphilis exhibit striking pathologic simtlarities and probably yield to the same treatment is a plausible theory, but why the succinimial should be used in preference to other more familiar mercuria salts seem strange. This salt is certainiy not only not to be found in text-books, but $I$ doubt if one pharmacist in a thousand carries it or has ever heard of it. Why should one firm or institute have a corner on something that ought to be available and purchasable anywhere? In what does this differ from the commercial spirit that sells acetanilid under the names of antikamnia and antifebrin, or that tries to monopolize the tuberculosis market with Iloyd" Aicsol or Robert's Hydrocine or reduce the corpulent with thyroid extract under title of marmola, rengo and other strange names? If the succinimid of mercury cures tuberculosis, does not the protoiodid, the biniodid, the mild or the strong chlorid or even the old fashioned unguentum hydrargyri? But if the succinimid, on the contrary, is the only salt of mercury that cures tuberculosis, then by all means let us get it on the official list at the next revision of the U. S. I. H. K. HGNRIKSEN, M.D.

ANswer.-Mercury succinimid is a definite chemical substance. It is the melcury salt of the imid of succinic acid. The Council on Pharmacy and Chemistry has accepted mercury succinimid as a non-proprietaly substance for inclusion with the next edition of New and Nonofficial Remedies, which will appear about January 1. There has been little if any call for the drug in the American market, consequently it may not be kept in stock by distributors or pharmacists.

\section{The Public Service}

\section{Army Changes.}

Memorandum of changes of stations and duties of medical officers, U. S. Army, week ending Dec. 5, 1908 :

Kennedy, J. M., major, ordered to report Dec. 1, 1908, for duty as acting chief surgeon, Department of California.

Mcrse, C. F., capt., relieved from duty at Fort Howard, Md., and directed to proceed to Fort Huachuca, Ariz., to accompany troops to the Island of Oahu, H. T., for duty there.

Williams, A. W., capt., granted leave of absence for 3 months. O'Reilly, R. M., brig.-general ; Russell, Frederick F., capt., and
Vaughan, v. C., Councilman, W. T., Musser, J. H., Lambert Alex., Flexner, Simon, Thayer, WW. S.. 1st lieuts., M. R. C., appointed a board to meet at Washington, Dec. 7,1908 , to investigate the question of immunizing the Regular, and, in case of war, the Volunteer Army against typhoid fever.

Trotter-Tyler, G., M. R. C., ordered from Fort Adams, R. I., to Fort Revere, Mass., for temporary duty.

Stephenson. A. V., M. R. C., honorably discharged from the service of the $\mathbf{U}$. $\mathrm{S}$.

Ender's, W. J., M. R. C., granted leave of absence for 10 days.

Kelly, I. P., M. R. C., relieved from duty at Fort Miley, Cal., and ordered to duty at the camp to be established on the Island of Oahu, H. T.

Vaughan, V. C., Councilman, W. T., Musser, J. H., Lambert, Alex., Flexner, simon, Thayer, $W$. S., M. R. C., ordered to active duty in the service of the U. S.

\section{Navy Changes.}

Changes in the Medical Corps, U. S. Navy, for the week ending Dec. 5, 1908 :

Curtis, E. E., asst.-surgeon, ordered to the Chattanooga.

Olson, G. M., asst.-surgeon, ordered to the Culgoa.

Stokes, C. F., surgeon, detached from command of the Relief and ordered home.

Spear, R.. surgeon, detached from the Relief and ordered to the Dode Island

Dessez, P. T., P. A. surgeon, detached from dnty at the naval hospital, Mare Island. Cal., December 31, and ordered to the Dunbar, A. W., surgeon, ordered to command the Relief.
Ducific Fleet, sailing from 